\title{
Tantangan Pelaksanaan Program Prevention of Mother to Child Transmission (PMTCT): A Systematic Review
}

\author{
Nimas Ayu Lestari Nurjanah ${ }^{1}$, Tri Yunis Miko Wahyono ${ }^{2}$ \\ Fakultas Kesehatan Masyarakat, Universitas Indonesia, Depok, Indonesia ${ }^{1,2}$ \\ nimas.ayu27@gmail.com ${ }^{1}$
}

Submitted 20 Desember 2018 Revised 11 Januari 2019 Accepted 20 Januari 2019

\section{ABSTRAK}

Latar Belakang: Penyakit HIV/AIDS masih menjadi masalah kesehatan global yang perlu ditangani termasuk pencegahan penularan HIV/AIDS dari ibu ke bayi. Pencegahan penularan dilakukan dengan melaksanakan program Prevention of Mother to Child Transmission atau program PMTCT. Program PMTCT dianggap berhasil menekan resiko penularan dari ibu ke bayi, namun hal tersebut berlum terlaksana secara baik dan menyeluruh, berbagai macam tantangan terjadi dalam penyelenggaraan program PMTCT.

Tujuan: Mengetahun tantangan yang terjadi dalam pelaksanaan program PMTCT

Metode: penelitian ini menggunakan systematic review berdasarkan Preferred Reporting Items For Systematic Reviews \& Meta-Analyses (PRISMA) untuk mengidentifikasi semua literatur yang di publikasikan dengan menggunakan kata kunci yang relevan.

Hasil: tantangan dalam pelaksanaan program PMTCT diantaranya adalah kurangnya informasi mengenai pengoabatn ART, kurangnya dukungan keluarga, beratnya beban kerja yang dialami petugas kesehatan dan terbatasnya alat tes HIV dan stok obat.

Kesimpulan: Keberhasilan pencegahan penularan HIV/AIDS dari ibu ke bayi sangat bergantung dari keterlibatan berbagai pihak, peran aktif dari tenaga kesehatan dalam memberikan pendidikan dan informasi mengenai penyakit HIV/AIDS kepada ibu dan keluarga tidaklah cukup tetapi harus ditambah dengan peran aktif dan dukungan keluarga kepada ibu HIV yang akan bertindak sebagai motivator dalam melaksanakan pencegahan penularan HIV/AIDS dari ibu ke bayinya

Kata Kunci: tantangan; PMTCT; HIV/AIDS hukum.

\section{ABSTRACT}

Background: HIV / AIDS is still a global health problem which needs to be addressed including prevention of HIV/ AIDS transmission from mother to child. Prevention of transmission is carried out by implementing the Prevention of Mother to Child Transmission or PMTCT program. The PMTCT program is considered successful in reducing the risk of mother-to-child transmission, but this has not been done well and thoroughly, various kinds of challenges have occurred in the implementation of the PMTCT program.

Objective: To know the challenges that occur in implementing the PMTCT program

Method: This study uses a systematic review based on Preferred Reporting Items For Systematic Reviews \& Meta-Analyzes (PRISMA) to identify all the literature published using relevant keywords.

Results: challenges in implementing the PMTCT program are the lack of information on HIV treatment, lack of family support, the heavy workload experienced by health workers and the limited availability of HIV testing equipment and drug stocks.

Conclusion: The success of efforts to prevent HIV / AIDS transmission from mother to child does not depend on one party only, but involves several parties, the active role of health workers in providing education and information about HIV / AIDS to mothers and their families is not enough but must be added with active roles and support from family members to HIV mothers as the primary motivator for good behavior in accordance with the guidelines for PMTCT. 


\section{PENDAHULUAN}

Penyakit HIV (Human Immunodeficiency Virus) merupakan penyakit yang disebabkan oleh virus yang menyerang sel darah putih sehingga menyebabkan turunnya sistem kekebalan tubuh, sedangkan AIDS (Acquired Deficiency Syndrome) merupakan kumpulan tanda atau gejala yang akan timbul karena turunnya sistem kekebalan tubuh karena infeksi oleh virus. HIV/AIDS masih terus menjadi masalah kesehatan yang utama bagi masyarakat global dan memerlukan perhatian yang serius karena setiap tahun jumlahnya bertambah.

Menurut UNAIDS (Joint United Nation Programme On HIV and AIDS) mengatakan di Dunia pada akhir 2017 terdapat lebih dari 36,9 juta orang hidup dengan HIV (35,1 juta orang dewasa dan 1,8 juta anak-anak), 1,8 juta kasus baru HIV, dan 940.000 orang didunia meninggal karena HIV/AIDS. Kasus HIV di Indonesia tahun 2017 terdapat 630.00 orang hidup dengan HIV dengan jumlah kasus baru sebesar 49.000 orang dan jumlah orang yang meninggal karena AIDS sebanyak 39.000 orang. (UNAIDS, 2018)

HIV/AIDS menjadi peyebab utama kematian usia reproduksi dibeberapa negara berkembang. Ibu hamil dengan HIV dapat menularkan virusnya kepada bayinya selama proses kehamilan, persalinan atau saat menyusui, bila selama proses tersebut tidak dilakukan intervensi tingkat penularan dari ibu ke bayinya bisa sebesar $15-14 \%$. Di Indonesia sendiri, ditemukan jumlah wanita usia $\geq 15$ tahun yang hidup dengan HIV yaitu 220.000 dan jumlah anak yang hidup dengan HIV yaitu 13.000. ( UNAIDS, 2017) Jumlah ini akan terus meningkat, seiring dengan meningkatnya prevalensi wanita usia 15-49 tahun yang menderita HIV maka beresiko dapat meningkatkan jumlah anak dengan HIV/AIDS. Oleh karena itu pemerintah melaksanakan program pencegahan penularan HIV dari ibu ke anak (PPIA) sebagai salah satu solusi menurunkan penularan virus HIV dari ibu ke bayinya. (Kemenkes RI, 2015)
Penularan HIV secara vertikal (Mother to Child Transmission) merupakan penularan HIV dari ibu HIV-positif ke anaknya selama kehamilan (5\%-10\%), persalinan (10\%-20), menyusui (10\%-15\%). MTCT menyumbang sebagian besar infeksi baru pada anak-anak. Jika dalam proses tersebut tidak dilakukan intervensi dapat meningkatkan penularan hingga $15-45 \%$. Penularan dari ibu ke bayinya dapat dicegah dengan memberikan ibu ARV pada kehamilan dan menyusio (WHO, 2018)

Berdasarkan data di dunia pada tahun 2017, ditemukan 59\% dari semua orang yang hidup dengan HIV mengakses pengobatan dengan rincian; $59 \%$ orang dewasa berusia $\geq 15$ tahun yang hidup dengan HIV memiliki akses ke pengobatan, dan $52 \%$ dari anak-anak berusia 0-14 tahun. Selain itu, 65\% dari wanita dewasa berusia $\geq 15$ tahun memiliki akses ke perawatan, hanya $53 \%$ pria dewasa yang berusia 15 tahun dan lebih tua memiliki akses. Pada tahun 2017 juga ditemukan bahwa, 80\% ibu hamil yang hidup dengan HIV memiliki akses ke obat antiretroviral untuk mencegah penularan HIV ke bayi mereka. (UNAIDS, 2018)

Program PPIA atau PMTCT merupakan progran yang direncakanan dan dijalankan pemerintah untug mencegah terjadinya penularan HIV/AIDS dari ibu ke bayinya. Program PMTCT mencegah penularan HIV/AIDS pada perempuan usia produktif dengan kehamilan HIV positif. Program PMTCT dilaksanakan pada perempuan usia produktif dengan melibatkan remaja dalam menyebarkan informasi tentang HIV/AIDS, selain itu juga meningkatkan kesadaran perempuan tentang bagaimana cara menghindari penularan virus HIV dan IMS ( Infeksi Menular Seksual) dan menjelaskan manfaat konseling dan tes HIV secara sukarela kepada kelompok yang berisiko, kader dan tenaga kesehatan. (WHO, 2009 dan Kemenkes 2015)

Kebijakan program PMTCT mulai dilaksanakan pada tahun 2005 dibeberapa daerah di Indonesia. Target yang harus dicapai 
adalah $100 \%$ ibu yang memeriksakan kandungannya menerima informasi mengenai Safe Motherhood, cara berhubungan seks yang aman, pencegahan dan penanganan Infeksi Menular Seksual (IMS), program PMTCT, konseling pasca tes dan pelayanan lanjutan ( Kemenkes, 2015)

Di Indonesia, ditemukan jumlah wanita usia $\geq 15$ tahun yang hidup dengan HIV yaitu 220.000 dan jumlah anak yang hidup dengan HIV yaitu 13 000. Ditemukan 12\% orang yang mengakses ARV dengan rincian; $12 \%$ pada orang dewasa $\geq 15$ tahun yang hidup dengan HIV dan 23\% dari anak-anak yang berusia 0-14 tahun. Sedangkan wanita hamil yang mengakses ARV sebanyak 10\%. Dimana dari 12.000 wanita hamil yang membutuhkan ARV, yang dapat mengakses ARV sebesar 1239 orang. (UNAIDS, 2017)

Berdasarkan Pediatric Spectrum of Disease Study beberapa infeksi oportunistik sering terjadi pada anak dengan infeksi HIV, yaitu pneumocystis carinii pneumonia (PCP) umumnya timbul pada usia 3 sampai 6 bulan, Mycobacterium avium complex (MAC) sering terjadi pada anak usia 5 tahun, candidiasis esofagus, infeksi bakterial berulang, dan tuberculosis (Lindergen, 2000)

Pencegahan terhadap infeksi oportunistik dibagi menjadi pencegahan primer yaitu mencegah terjadinya infeksi, dan pencegahan sekunder yaitu pemberian obat setelah infeksi terjadi. ( Djauzi, 2002) Pencegahan terhadap infeksi oportunistik dapat dihentikan apabila terdapat peningkatan dari CD4+ >200/mL selama 3 bulan. (Djauzi, 2002 dan USPHS, 2001)

Anak dengan infeksi HIV sebaiknya diberi imunisasi sesegera mungkin dengan vaksin inactivated sedangkan imunisasi dengan menggunakan vaksin hidup attenuated pada anak dengan infeksi HIV perlu dilakukan secara hati-hati, dan sebaiknya tidak diberikan apabila di dapatkan penekanan sistim imun atau gejala klinis infeksi HIV. (American Academi of pediatrics, 2000 dan Krist 2002)

Beberapa tahun terakhir berbagai macam layanan pengendalian HIV di indonesia mengalami kemajuandan jumlah orang yang yang memanfaatkan juga bertambah sehingga tujuan pengendalian HIV dapat terlaksana (Kemenkes, 2015). Namun, masih ada beberapa sub bagian dari program yang belum memenuhi target. Hal ini terlihat dari jumlah wanita hamil yang mengakses ARV sebanyak 10\%. Dimana dari 12.000 wanita hamil yang membutuhkan ARV, yang dapat mengakses ARV hanya sebesar 1239 orang. (UNAIDS, 2017)

Berdasarkan latar belakang tersebut kami akan membahas tantangan apa saja yang terjadi dalam pelaksanaan program PMTCT, agar tantangan tersebut tapat teratasi sehingga tujuan dari program tersebut dapat dicapai dan dapat menekan penularan dari ibu ke anak.

\section{Metode Strategi pencarian}

Beberapa strategi pencarian digunakan untuk mengidentifikasi studi yang relevan. Pencarian data dan informasi menggunakan situs elektronik sebagai sumber data. Hasil pencarian artikel digunakan PRISMA (Preferred Reporting Items for Systematic Reviews \& MetaAnalyses) untuk instrumen dan menggunakan flowchart berdasarkan daftar checklist PRISMA 2009, menghilangkan artikel yang tidak relevan dengan kriteria identifikasi, penyaringan, kelayakan, dan akhirnya mengunduh artikel yang relevan. Langkah pertama adalah $\mathrm{m}$ e $\mathrm{m} \mathrm{b}$ u $\mathrm{k}$ a

$d a t a b$ a s e https://www.scopus.com/home.uri dan https://www.proquest.com kemudian menggunakan pencarian lanjutan.

\section{Seleksi dokumen}

Seleksi dokumen menggunakan kata kunci "Challenge" OR "Defiance" AND "Prevention of Mother To Child Transmission" OR "PMTCT" pada jurnal di Scopus dan Proquest. Kami menemukan 311 Dokumen berdasarkan full text akses dokumen gratis, Dokumen, berdasarkan tahun publikasi (3 tahun) dan berdasarkan Bahasa inggris, Kemudian menyeleksi jurnal berdasarkan judul dan 
abstrak 29 Dokumen dan seleksi secara keseluruhan (full text) 4 dokumen untuk di analisis

\section{Kriteria Inklusi dan eksklusi}

Kriteria inklusi dokumen yang kami anggap tepat untuk melakukan tinjauan sistematis adalah jurnal dari penelitian, dilaporkan dalam Bahasa inggris, di terbitkan 3 tahun terakhir (2016-2018), Kami menggunakan tinjauan sistematis pada semua jenis desain studi. Studi dengan peserta wanita dengan HIV positif, petugas, kader kesehatan yang menjalankan program PMTCT. Lokasi penelitian melibatkan negara-negara dengan jumlah HIV tinggi dan menerapkan PMTCT. Studi dikeluarkan jika studi berkaitan dengan penularan, penyebaran HIV, dampak HIV pada ibu dan anak serta yang tidak berkaitan dengan Program PMTCT.
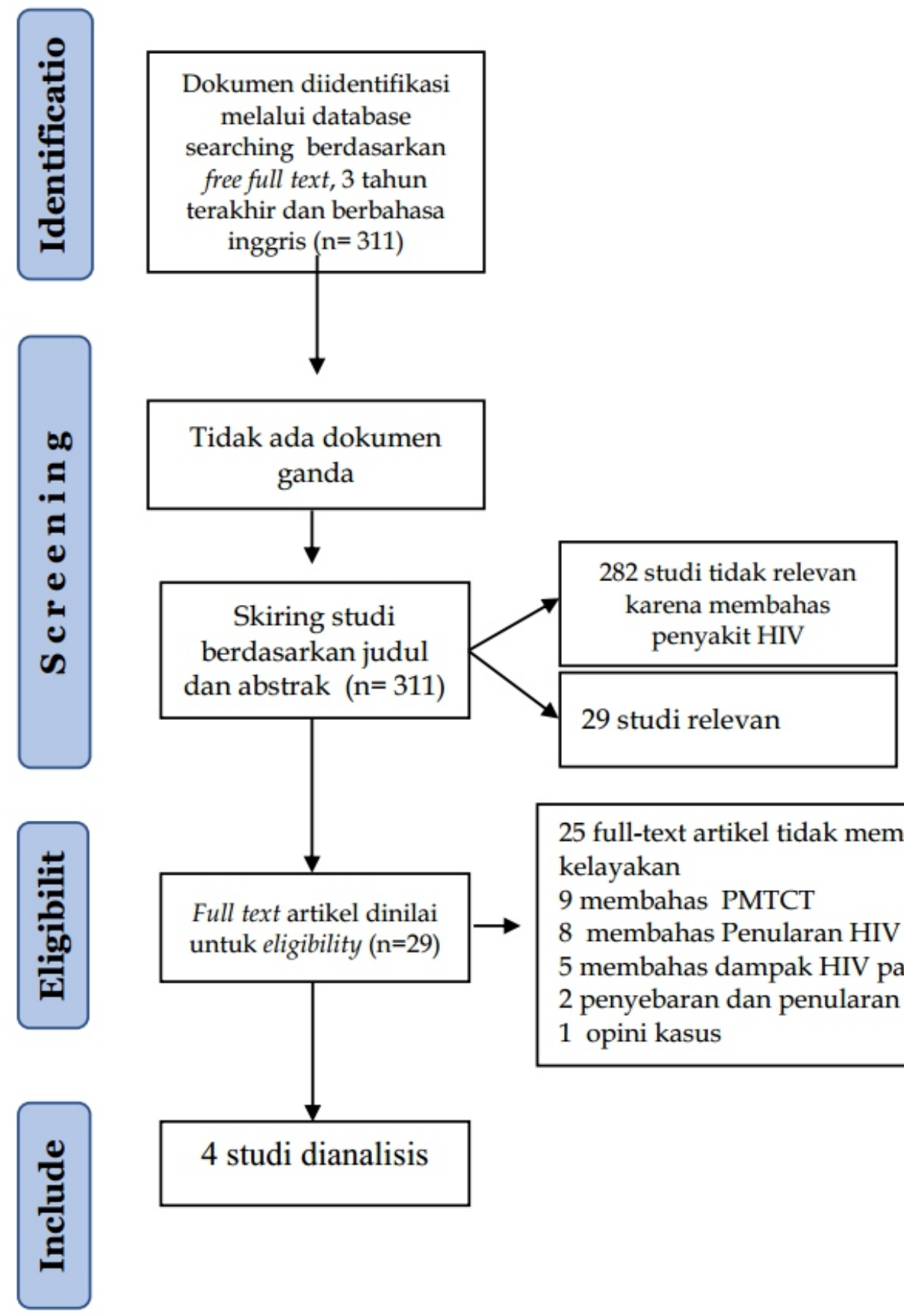

25 full-text artikel tidak memenuhi persyaratan kelayakan

9 membahas PMTCT

Full text artikel dinilai untuk eligibility $(\mathrm{n}=29)$

8 membahas Penularan HIV dari ibu ke anak

5 membahas dampak HIV pada ibu/anak 2 penyebaran dan penularan HIV anak 1 opini kasus

Gambar 1: Hasil pencarian literatur 
Tabel 1: Ringkasan penelitian yang menunjukkan tantangan dalam pelaksanaan program PMTCT

\begin{tabular}{|c|c|c|}
\hline No & Penulis, Tahun, Judul & Lokasi \\
\hline 1 & $\begin{array}{l}\text { Katiyari, L, Chouraya, } \\
\text { C, etct, 2016. Lessons } \\
\text { learned from the PMTCT } \\
\text { program in Swaziland: } \\
\text { challenges with accepting } \\
\text { lifelong ART for pregnant } \\
\text { and lactating women - a } \\
\text { qualitative study }\end{array}$ & $\begin{array}{l}\text { Swaziland: } \\
\text { Shiselweni, } \\
\text { Lub o m bo, } \\
\text { Hhohho, dan } \\
\text { Manzini. }\end{array}$ \\
\hline
\end{tabular}

2 Etoori, D, Kerschberger, Southern 2018, Challenges and swazilan successes in the implementation of option $B+$ to prevent mother-tochild transmission of HIV in southern Swaziland

3 Schurter, R, Sousa, Mozambique O,etc, 2016, Performancebased incentives may be

Appropriate to address challenges to

Delivery of prevention of vertical

Transmission of HIV services in rural

Mozambique: a qualitative investigation

4 Suryavanshi, N, Mave, India V, etc, 2018, Challenges and opportunities for outreach workers in the Prevention of Mother to Child Transmission of HIV (PMTCT) program in India
665 Cohort Program PMTCT dianggap bersahil dalam menekan penurunan virus pada ibu dan menurunkan kejadian penularan ke bayi, tantangan program PMTCT diantaranya ganggun effek dari pengoabatan yang tinggi, kurangnya partisipasi dari pasangan ibu bayi dalam mengecek jumlah VL dll. (Etoori, 2018)

Kualitatif Semua petugas kesehatan (perawat, kader kesehatan, dll ) bekerja dengan motivasi intrisik dengan beban kerja yang berat, system pelaporan yang belum bak serta upah yang rendah. (Schuster 2016)

60 Kualitatif Tantangan personal petugas : memastikan layanan PMTCT yang tepat untuk pasiennya

Tantangan personal pasien : keengganan pasien untuk mengungkapkan status HIV kepada pasangan atau keluarga hal tersebut berdampak pada kepatuhan terhadap ART, ketidakteraturan kunjungan dan gagalnya ART.

Tantangan Sosial : adanya stigma dan ketakutan mengungkapkan status HIV sehingga menolak untuk melakukan perawatan.

Tantangan structural : seringnya kekurangan atau kehabisan persediaan obat terutama alat tes HIV hal tersebut menyebabkan hilangnya kepercayaan pada program (Suryavanshi, 2018) 


\section{HASIL}

Kami mengidentifkasi database berdasarkan beberapa kriteria seperti dokumen dapat di akses gratis dan full text, berbahasa inggris danditerbitkan dalam 3 tahun terakhir kami mendapatkan 311 dokumen, kemudian kami berdasarkan judul dan abstrak didapatkan 29 studi yang relevan dan 282 studi yang tidak relevan, studi tersebut membahas seputar penyakit HIV secara menyeluruh seperti epidimiologi HIV, faktor risiko HIV, dampak dari HIV dan beberapa tantangan yang dihadapi seperti masih sulitnya menjangkau orang yang menjadi faktor risiko HIV karena beberapa alasan seperti masih belum terbukanya orang tersebut dan faktor demografi. 29 studi yang relevan di analisis berdasarkan full text terdapat 25 artikle yang tidak memenuhi standar kelayakan (eligibility) 25 artikel tersebut membahas mengenai penularan HIV secara vertikal dan program PMTCT.

Kami mengidentifikasi 4 article, penelitian dilakukan dibeberapa negara seperti Swazilan, Shiselweni, Lubombo, Hhohho, Manzini. Mozambique dan india. 3 penelitian menggunakan desain kualitatif dengan FGD dan wawancara tidak terstruktur dan 1 penelitian menggunakan desain cohort. Penelitian berisi tantangan dalam menjalankan program Prevention of Mother To Child Transmission (PMTCT) baik yang di lakukan oleh ibu hami dengan HIV positif, ataupun pertugas kesehatan (tenaga kesehatan, kader kesehatan).

Dari 4 artikel yang dianalisis tantangan dalam menjalankan program PMTCT bisa muncul dari pasien ataupun dari petugas yang melaksanakan program. Tantangan yang dapat terjadi pada pasien meliputi kurangnya informasi tentang program pencegahan penularan HIV dari ibu ke anak mulai dari tujuan, manfaat, efek samping serta informasi mendalam mengenai ART, selain itu keterlibatan pasangan dan keluarga juga berpengaruh terhadap berjalannya program PMTCT, keterlibatan tersebut meliputi keikut sertaan dalam proses pengobatan seperti keaktifan mengecek jumlah viral load dan komitmen mendampingi selama pengobatan. Komitmen penderita dalam menjalankan terapi ART juga menjadi tantangan terendiri karena terapi tersebut berlangsung seumur hidup. Selain itu keengganan pasien untuk mengungkapkan status HIVnya juga menjad tantangan dalam pelaksanaan PMTCT.

Tantangan dalam menjalankan program PMTCT yang terjadi pada petugas kesehatan (tenaga kesehatan, kader kesehatan) meliputi tidak seimbangnya beban kerja dengan upah yang di dapat, selain itu terjadi kesulitan dalam memastikan layanan PMTCT yang tepat untuk pasiennya, tantangan lain adalah memastikan pasien komitmen menjalankan terapi dengan menghilangkan stigma yang melekat di masyarakat, ketersediaan obat dan alat tes hiv juga menjadi tantangan dalam pelaksanaan program. Dengan tidak tersedianya obat atau alat tes pasien menjadi hilang kepercayaan pada program yang dilaksankan.

\section{PEMBAHASAN}

Pada tahun 2020 indonesia menargetkan 3 zero yaitu zero new infection, zero death related aids dan zero discrimination target tersebut juga sejalan dengan target yang ingin di capai UNAID pada tahun 2020 yaitu 90\% orang mengatahui status HIVnya, 90\% orang yang terkena HIV mendapatkan ART dan 90\% orang yang mendapat ART mengalami penurunan viral load. Target tersebut dilakukan dengan cara melakukan pencegahan penularan HIV, meningkatkan akses pemeriksaan HIV, pengobatan HIV, meningkatkan retensi pengobatan, meningkatkan kualitas hidup ODHA, mitigasi dampak sosial ekonomi epidemi HIV pada individu, keluarga dan masyarakat untuk menjaga produktivitas dan sumber daya manusia Indonesia. (Komisi penanggulanga HIV dan AIDS, 2015)

Dalam mewujudkan target 3 zero salah satu cara yang digunakan adalah dengan cara mencegah penularan HIV, penularan tersebut dapat berasal dari ibu ke anaknya. Pencegahan 
tersebut sesuai dengan rekomendasi WHO pada tahun 2010 dimana semua ibu hamil ditawarkan untuk melakukan test HIV, akan tetapi cakupan ibu hamil yang melakukan tes HIV masih rendah yaitu $<1 \%$.

Upaya pencegahan penularan HIV/AID dari ibu ke bayi adalah dengan program PMTCT (Prevention of Mother to Child Transmission). Dalam pelaksanaanya PMTCT mempunyai empat prong/pilar yaitu:

a. mencegah terjadinya penularan HIV pada perempuan usia reproduktif.

b. mencegah kehamilan yang tidak direncanakan pada ibu dengan HIV.

c. mencegah terjadinya penularan HIV dari ibu hamil dengan HIV kepada bayi yang dikandungnya.

d. memberikan dukungan psikologis, sosial, dan perawatan kepada ibu dengan HIV beserta bayi dan keluarganya. VCT (Voluntary Counseling and Testing) adalah layanan tes, konseling, dukungan, akses untuk terapi suportif, terapi infeksi oportunistik, dan ART (Antiretroviral Therapy). (Kemenkes, 2015)

Bagi tenaga kesehatan dalam rangka mendorong ibu hamil melakukan tes HIV dapat dikategorikan sebagai Provider Initiated Testing and Counseling (PITC).

PICT merupakan kebijakan pemerintah di layanan kesehatan dimana semua tenaga kesehatan harus menganjurkan tes hiv terkusus untuk ibu hamil. Kegiatan PITCT berisi kegiatan memberi anjuran dan pemeriksaan HIV dengan prinsip pasien sudah mendapat informasi yang cukup mengenai HIV dan setuju dilakukan tes HIV. ( Ernawati 2016)

Tenaga kesehatan memberikan informasi tentang HIV, menawarkan tes HIV, melaksanakan tes HIV, menyampaikan hasil tes dan melakukan konseling pasca tes dan melakukan rujukan ke unit perawatan, dukungan dan pengbatan (PDP) jika hasil tes positif. Hambatan yang dialami tenaga kesehatan adalah tidak semua tenaga kesehatan mampu dalam menyampaikan informasi mengenai HIV, tidak semua mampu menawarkan tes HIV hingga pasien mau untuk diperiksaa, keterbatasan jumlah alat tes dan pelaporan yang belum lengkap dan akurat serta masih kuatnya stigma mengenai HIV. (Sudrani, 2018)

Pencegahan Penularan HIV dari Ibu ke Anak (PPIA) atau Prevention Mother to Child Transmission (PMTCT) merupakan program pemerintah untuk mencegah penularan virus HIV/AIDS dari ibu ke bayi yang dikandungnya. Program tersebut mencegah terjadinya penularan HIV/AIDS pada perempuan usia produktif kehamilan dengan HIV positif, penularan HIV/AIDS dari ibu hamil ke bayi yang dikandungnya. (WHO, 2009 dan Kemenkes 2015)

Dalam pelaksanaan PMTCT dimulai dengan pelayanan ANC terpadu, konseling dan tes HIV wajib pada ibu hamil pada saat ANC pertama kali. Konseling pasca tes bagi ibu hamil yang hasilnya positif dilaksanakan bersamaan dengan (couple counseling), pemberian kondom diberikan sebagai alat pencegahan penularan IMS dan HIV.

Terapi antriretroviral pada ibul hamil dengan HIV positif mengikuti pedoman ART untuk orang dewasa. Pada ibu hamil, pasien TB dan Hepatitis terapi dapat langsung diberikan tanpa melihat stadium klinis dan jumlah CD4, tetapi pemeriksaan CD4 juga diperlukan untu pemantauan pengobatan. Untuk ibu hamil dengan HIV positif terapi yang direkomendasikan menggunakan kombinasi tiga obat (2 NRTI + 1 NNRTI). Perlu dihindari penggunaan "triple nuke" (3 NRTI). Paduan obat ARV Kombinasi Dosis Tetap / Fixed Dose Combination (FDC): TDF (300mg) + 3TC (300mg) + EFV (600mg). (Kemenkes, 2015)

Untuk ibu hamil yang sudah mengetahui status HIV sebelum hamil terapi ARV tetap dilanjutkan sesuai panduan sebelum hamil, jika ibu mengetahu status HIVnya pada saat hamil maka diberikan ARV tanpa melihat stadium klinis dan jumlah CD4nya. Untuk ibu yang mengetahui status HIVnya pada saat persalinan segera diberikan ARV. (Kemenkes, 2015) 
Hasil analisis dari 4 penlitian mengemukanan tantangan dalam pelaksanaan program PMTCT baik tantangan yang dirasakan penderita HIV ataupun petugas kesehatan yang melaksanakan program, tantangan tersebut berasal dari faktor internal ataupun eksternal.

Dalam pelaksanaan program PMTCT yang dialami ibu dengan status hiv diantaranya kurangnya informasi yang berkaitan dengan program PMTCT, kurangnya komitmen dalam menjalankan ART sehingga pengobatan tidak maksimal serta masih banyak stigma dimasyarakat sehingga ibu enggan mengungkapkan status HIVnya. Berbagai macam tantangan yang di hadapi tersebut menunjukkan bahwa peran tenaga kesehatan dalam penanganan kasus HIV/AIDS perlu ditingkatkan seperti meningkatkan konseling pada saat diagnosis HIV dan pada saat memulai ART. Kemampuan petugas kesehatan dalam melaksanakan konseling juga berpengaruh terhadap keberhasilan program PMTCT. Selain kemampuan konseling, menurut resty Asmaurah dalam penelitiannya mengatakan kepekaan dan peran petugas kesehatan sangat berpengaruh dalam pelaksanaan program PMTCT, seringnya interaksi antara tenaga kesehatan dan pasien juga akan membawa pemahaman terhadap kondisi fisik maupun psikis akan lebih baik, selain itu juga akan mempengaruhi rasa pecaya diri dan penerimaan kehadiran petugas kesehatan. Edukasi dan konseling juga sangat berpengaruh terhadap keberhasilan program (Asmauryanah, 2014).

Komitmen sangat penting dalam pelaksanaan PMTCT, komitmen tersebut mencakup. Keterturan meminum ARV seumur hidupnya. Komitmem tersebut bukan hanya dari pasien yang menjalankan terapi tetapi juga dari orang-orang sekitarnya. Menurut penelitian wenny wahyu mengatakan peran suami dan keluarga memperlihatkan pengaruh yang positif pada pastisipasi pasien menjalankan program PMTCT. Hal tersebut sesuai dengan teori yang dikemukakan oleh
Green dimana peran suami dan keluarga termasuk faktor reinforsing yang akan membentuk prilaku baru yaitu faktor penguat seseorang mempengaruhi ibu hamil positif HIV menjalankan program PMTCT. (Wahyuni, 2014)

Tantangan yang dihadapi oleh petugas pelaksana program PMTCT diantaranya terlalu banyak beban kerja dan upah yang tidak seimbang, beban kerja tersebut meliputi melkukan pemantauan, pencatatan dan pelaporan kasus serta keberjalannannya program serta memastikan komitmen pasien dalam ART. Terlalu banyaknya beban kerja bisa disebabkan kurangnya jumlah tenaga kesehtan atau pesebaran tenaga kesehatan yang tidak merata. Tanntangan tersebut akan mengurangi semangat kerja dan kinerja tenaga kesehatan dalam melaksanakan program PMTCT. Karmila dalan penelitiannya menggatakan bahwa ODHA yang telah bertemu tenaga kesehatan memiliki presepsi positif terhadap terapi ARV. Presepsi posotif tersebut didapat setelah petugas kesehatan memberikan konseling dan motivasi untuk pelaksanakan program HIV (Kamila, 2010).

Selain itu menurut Sanders dalam penelitiannya mengatakan ibu hamil dengan HIV positif yang tidak mendapat dukungan dari keluarga maupun tenaga kesehatan akan mengalami berbagai macam situasi seperti kecemasan akan keadaannya dan bayinya, penularan ke bayinya, proses persalinan yang akan dijalaninya. Kecemasan tersebut akan terus berlangsung hingga ada kepastian bahwa bayinya tidak tertular virus HIV. (Sanders, 2007).

Ketersediaan alat tes HIV dan obat ARV juga menjadi hal yang penting dalam pelaksanaan PMTCT, jika kurangnya ketersediaan alat tes dan obat akan menyebabkan orang enggan mengecek status hiv pada dirinya. Hal tersebut akan memperburuk kondisi pesebaran HIV dan akan menjadi sangat mudah meningkatnya kasus HIV karena tidak ada penanganan terhadap orang dengan status HIV. Peran 
pemerintah terkait penyediaan dan penyaluran alat tes HIV dan Obat ARV sangat diperlukan. Dengan manajeman yang baik makan kebutuhan alat tes HIV dan obat ARV tersebut akan terpenuhi.

\section{KESIMPULAN}

Berhasilnya pelaksanaan pencegahan penularan HIV/AIDS dari ibu kebayinya bergantung pada beberapa pihak. Peran aktif tenaga kesehatan dalam pemeberian konseling dan edukasi mengenai HIV tidak hanya dilakukan pada ibu, tetapi juga dilakukan pada keluarganya. Informasi pada keluarga saja tidak cukup tetapi juga perlunya peran aktif dan dukungan anggota keluarga sebagai motivator ibu dalam menjalankan program PMTCT.

\section{DAFTAR PUSTAKA}

American Academy of Pediatrics. (2000). Human immunodeficiency virus infection. Dalam: Pickering LK, penyunting. 2000 Red Book: report of the Committee on infectious diseases. Edisi 25. Elk Grove Village, IL. American Academy of pediatric; 325-50

Anders, L.B. (2007). Women's Voices: The Lived Experience of Pregnancy and Motherhood After Diagnosis With HIV. Journal Of The Association Of Nurses In Aids Care, 19 (1) 47-57.

Asmauryanah, R. (2014). Pencegahan Penularan HIV Dari Ibu Ke Bayi Di Puskesmas Jumpandang Baru Makassar.Bagian Epidemiologi Fakultas Kesehatan Masyarakat Universitas Hasanuddin. Tesis. Makassar: Universitas Hasanuddin

Djauzi S, Djoerban Z. (2002). Penatalaksanaan HIVIAIDS Di Pelayanan Kesehatan Dasar. Jakarta: Balai penerbit Fakultas Kedokteran Universitas Indonesia. 1-71

Ernawati, suryoputro, a.etc. (2016). Niat Ibu Hamil Untuk Test HIV Di UPT ( Unit Pelayanan Terpadu) Puskesmas Alun-Alun Kabupaten Gresik. Jurnal promosi kesehatan indonesia vol 11 no 1.
Etoori, D, Kerschberger, B, etc. (2018). Challenges and successes in the implementation of option $B+$ to prevent mother-to-child transmission of HIV in southern Swaziland. BMC Public Health. 18:374hal 2-9.

Kamila, N., Siwiedrayanti, A. (2010). Persepsi Orang dengan HIV dan AIDS terhadap Peran Kelompok Dukungan Sebaya. Jurnal Kemas 6(1):36-43.

Katiyari, L, chouraya, C, etc. (2016). Lessons learned from the PMTCT program in Swaziland: challenges with accepting lifelong ART for pregnant and lactating women $-a$ qualitative study. BMC Public Health. $16 ; 1119$

Kementerian Kesehatan RI (2015) Pedoman Manajemen Program Pencegahan Penularan HIV dan Sifilis Dari Ibu Ke Anak. Jakarta

Kementerian Kesehatan RI (2015) Pedoman Pelaksanaan Pencegahan Penularan HIV dan SIfilis dari Ibu ke Anak Bagi Tenaga Kesehatan. Jakarta. Tersedia pada: http://siha.depkes.go.id/portal/files_uplo ad/Manlak_PPIA_2015.pdf.

Komisi penanggulangan HIV dan AIDS. (2015). Strategi Dan Rencana Aksi Nasional 2015-2019 Penanggulangan HIV Dan AIDS $D i$ Indonesia. Tersedia pada http://siha.depkes.go.id/portal/files_uplo ad/SRAN_2015_2019_FINAL.pdf. Diakses pada 19 desember 2018.

Krist AM, Faucher AC. (2002) Management of newborns exposed to maternal HIV infection. Am Fam Physician;65: 2049-56,2061

Lindegren ML, Steinberg SMS, Byers RH Jr.(2000). Epidemiology of HIVIAIDS in children. Pediatr Clin North Am 47:1-20

Schuster, R, Sousa, O, etc. (2016). Performancebased incentives may be appropriate to address challenges to delivery of prevention of vertical transmission of HIV services in rural Mozambique: a qualitative investigation. Jounal human resources for health. 14:60

Sudrani, sitti. (2018). Provider initiative test and counseling (PITC) sebagai upaya perluasan tes HIV pada populasi khusus. Public health 
symposium. 7-9 mei. Yogyakarta, indonesia

Suryavanshi, N, Mave, V, etc.2018. Challenges and opportunities for outreach workers in the Prevention of Mother to Child Transmission of HIV (PMTCT) program in India. Jounal plos one 13(9).

UNAIDS (2017). AIDS info; Country factsheets Indonesia 2016. hal. 1-6. Tersedia pada: https://aidsinfo.unaids.org/\%0D. diakses tanggal 2 desember 2018

UNAIDS (2018). Global HIV \& AIDS statistics 2018 fact sheet. Tersedia pada: http://www.unaids.org/en/resources/fact -sheet. Diakses pada 4 Desember 2018

Wahyuni, Wenny. 2014. Partisipasi Orang dengan
HIVIAIDS (ODHA) Ibu Rumah Tangga pada program Prevention Mother to Child Transmission (PMTCT) di Kota Semarang. Jurnal Promosi Kesehatan Indonesia 9(2): 206-217

WHO (2009) A Guide for Adaptation and Implementation. Tersedia pada https://www.who.int/hiv/topics/treatme nt/guide_for_adaptation.pdf diakses pada 5 desember 2018

WHO (2018) HIV / AIDS : Key facts, Risk factors. $\mathrm{T}$ e r s e d i a $\quad \mathrm{p}$ a d a https://www.who.int/news-room/factsheets/detail/hiv-aids diakses pada 2 Desember 2018 